Ying Yang

\title{
AFRICAN SOCIAL NETWORKS IN CHINA: A COMPARATIVE STUDY OF COMMUNITIES IN GUANGZHOU AND YIWU
}

\author{
Nagoya University, \\ Japan 464-8601 Nagoya-shi, Chikusa-ku, Furo-cho
}

After the first Africans appeared in China in 2000, their communities were formed in Guangzhou and later in Yiwu. Being the third largest city in China, Guangzhou benefited from its proximity to Hong Kong and the Pearl River. These and some other city's advantages attracted African traders. In contrast, Yiwu, despite being ranked a county-level city in the Zhejiang Province, came to prominence as the world's largest wholesale market. Yiwu also attracted Arab and African traders. Being separated from each other by only two-hour plane trip or 13-hour train trip, the two cities are not so distant geographically. However, because of the difference in size, lifestyle, business patterns, local government policies and the patterns of Chinese residence, each of the two African communities developed in its own peculiar way. This study is based on fieldwork, carried out in both areas. It aims to analyze the differences of African communities and their networks in Yiwu and Guangzhou. What attracts Africans to these cities? What is their objective? Why do they stay in these two particular cities, and not in others? Do they have an intention to move to other cities or other countries? This study also tries to discover, if there are links between the African communities in the two cities and examine patterns of social networks' development in both locations. Refs 6 . Figs 6 . Table 1.

Keywords: African traders, networks, social capital, foreign residents, foreign communities.

\section{СОЦИАЛЬНЫЕ СЕТИ АФРИКАНЦЕВ В КИТАЕ: СРАВНИТЕЛЬНОЕ ИССЛЕДОВАНИЕ ОБЩИН В ГУАНЧЖОУ И ИУ}

Ин Ян

Нагойский университет, Япония, 464-8601, Нагоя, Тикуса-ку, Фуро-тё

После того как первые выходцы из Африки появились в Китае в 2000 г., их общины были сформированы в Гуанчжоу и позднее в городе Иу. Являясь третьим крупнейшим городом в Китае, Гуанчжоу стал привлекательным благодаря своей географической близости к Гонконгу и реке Пёрл-Рива. Эти и некоторые другие преимущества города привлекали торговцев из Африки. В отличие от Гуанчжоу, Иу, будучи всего лишь районным центром в провинции Чжэцзян, стал широко известен как крупнейший в мире оптовый рынок. Иу также стал привлекать торговцев из арабских и африканских стран. Находясь на расстоянии всего двухчасового перелета или тринадцатичасового переезда на поезде, эти два города не так сильно отдалены географически. Однако из-за различий в масштабе, стиле жизни, политике местных властей и особенностях проживания каждая из африканских общин сформировалась по-своему. Статья основана на полевых исследованиях, проведенных в двух городах. Исследование ставит своей задачей проанализировать различия африканских общин в Гуанчжоу и Иу. Что привлекло выходцев из Африки в эти города? Какова их цель? Почему они выбрали именно эти два города, а не какие-либо иные? Исследование также стремится установить, есть ли связь между африканскими общинами в этих двух городах, и выявить особенности развития социальных сетей мигрантов в каждом из них. Библиогр. 6. Ил. 6. Табл. 1.

Ключевые слова: африканские торговцы, социальные сети, социальный капитал, иностранные жители, иностранные общины.

(c) Санкт-Петербургский государственный университет, 2017 


\section{Introduction}

As we know, China is not traditionally a country of immigration. However, since 1978, after the introduction of the reform and opening-up policy, the number of foreigners has been increasing every year. According to the China National Tourism Administration, in 2015 the number of foreign visitors was approximately 26 million. ${ }^{1} 20 \%$ of the foreigners arrived for business, and $30 \%$ were there for tourism. African visitors accounted for 580,000 people, $21 \%$ of all the foreign visitors, but in contrast to the other visitor groups, 210,000 Africans, or almost $40 \%$ of them, came for business, and only $30 \%$ were tourists. Unlike Beijing and Shanghai, two famous centers of trade in China, Guangzhou and Yiwu are most famous as centers of small commodity wholesaling, which is the most attractive kind of business to African traders. This is the reason why they keep coming to the two cities, and why I chose these two cities as the place to observe the groups of African traders in China.

This study, based on fieldwork in both areas, attempts to analyze the differences of African communities and their networks in Yiwu and Guangzhou. What attracts them to these cities? What is their objective? Since research on migration to China is still limited, this paper will attempt to fill this gap and contribute to the field of transmigration and global migration studies.

Guangzhou as the third largest city in China, and is also known as the southern gateway to the country. It is located near Hong Kong and Shenzhen. According to Bredeloup [1, p. 30-31], African traders began coming to Guangzhou in 2000 after the Asian Financial Crisis of 1998. Some of them had previously owned small-scale businesses in South-East Asia and moved to Hong Kong on the look-out for more business opportunities and later crossed the border to settle down in Guangzhou. Some studies showed that an African ethnic enclave formed on the Xiaobei road in Yuexiu district in this city [5, p. 8]. As the pioneer researcher of Guangzhou's African trading community, Li Zhigang told me when I interviewed him in 2009, there were approximately 30,000 African traders residing in China on a long-term basis with legal or illegal status. In contrast to Li's viewpoint, Bredeloup [1] and Haugen [3] were more specific after doing studies inside the communities. Bredeloup distinguishes three types of Africans, depending on their residence: businessmen, adventurers, and relatives of residents. Haugen concentrated on Nigerians, the largest group of African traders in Guangzhou. Bredeloup and Haugen also mentioned that some Africans moved to Guangzhou searching for opportunities to later migrate to Europe, but failed to do so and remained in Guangzhou without work or any income [1, p. 40]. Haugen called this kind of residence "the second state of immobility" [3, p. 72]. This signifies that some migrants are unable to move out of the host country. Haugen also mentioned that China was a springboard for some African migrants who wanted to move to developed countries such as Japan, Australia or the EU states [3, p. 71].

Academic research on Africans in Guangzhou started in 2008, but the research about Africans in Yiwu has been negligible. Most research on foreign residents in Yiwu does not distinguish African migrants as a separate category. However, the number of African traders has recently increased in Yiwu in contrast to Guangzhou.

${ }^{1}$ China National Tourism Administration. URL: http://www.cnta.gov.cn/zwgk/lysj/201601/ t20160118_758408.shtml retrieved on 22 May 2016. 
Since their numbers have been increasing, African migrants have formed several social networks both in Guangzhou and Yiwu. Social networks are important for them in accumulating so-called social capital that, according to Kim's definition, is "an emergent relative property which can be accessed through constructive efforts to bring benefits to personality or group" [4, p. 238]. Lin defined social capital as "a resource or an operation which was embedded in social networks that people access or utilize to do any kind of activity" [5, p. 32]. According to these definitions, social capital is accumulated in social networks. People tied by social networks can access various resources easier than people who are not. That is the reason I tried to observe networks constructed by African migrants in China.

In this article, I will compare the influence of the city size on the African community and the migration policy of the local governments to examine the differences between Guangzhou and Yiwu and reveal the characteristics of African traders' networks.

\section{Background: The comparison of Guangzhou and Yiwu and their treatment of migrants}

Guangzhou, known as the southern gateway of China, is located near Hong Kong and Shenzhen. Guangzhou is also the heart of Pearl River Delta of China and the capital city of Guangdong Province. The city area is 7,434 square kilometers, and the population is

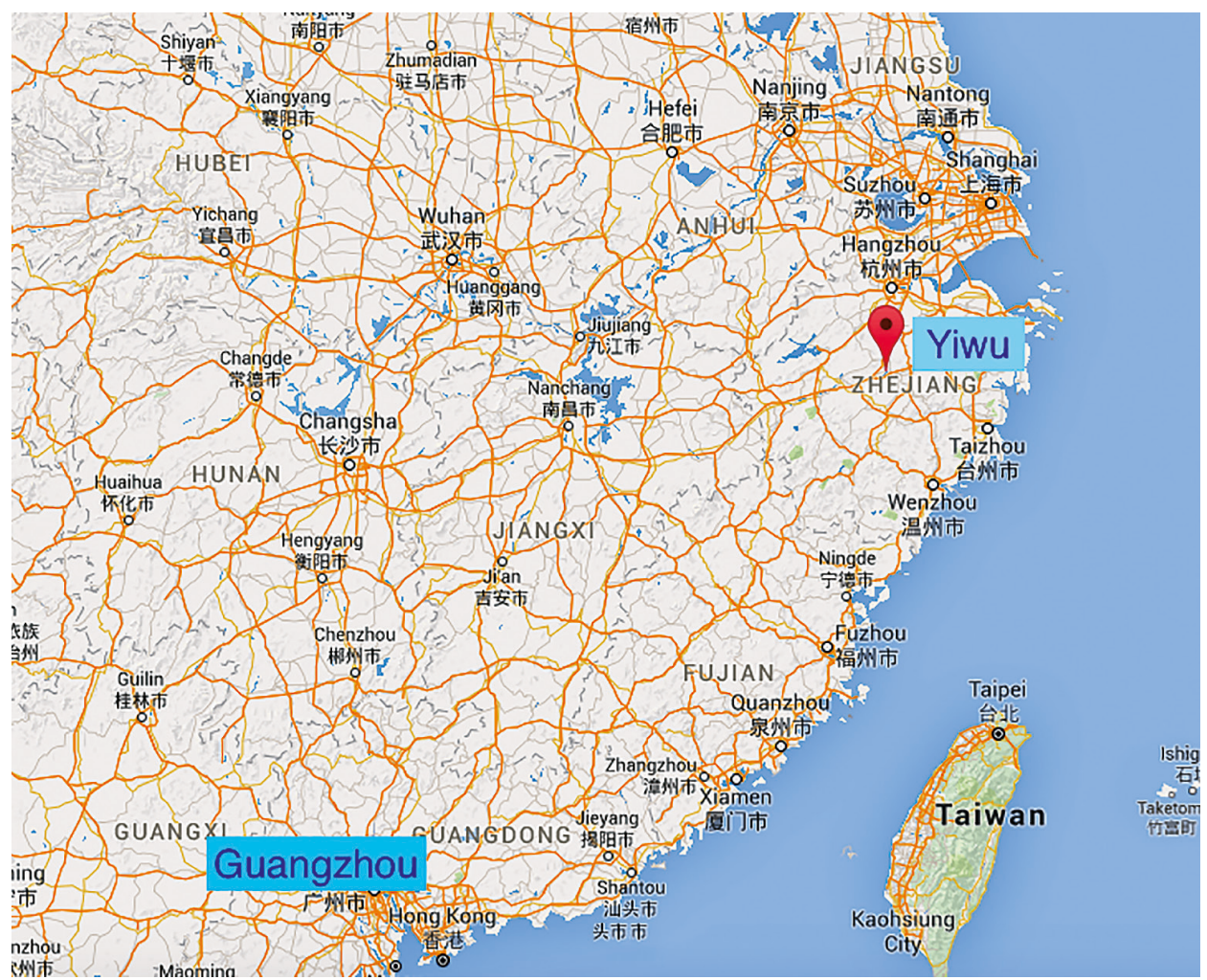

Chart 1

S o u r c e: Google Maps. Retrieved on 17 June 2016. 
12.7 million. As the third largest city in China after Beijing and Shanghai, Guangzhou has attracted many foreigners to visit. Yiwu is a county-level city located in southeast China. It is marked red on Chart 1 below. Yiwu is part of Jinhua City in Zhejiang Province. The area is only 1,105 square kilometers, and the population is 200,000. However 143,000 people in Yiwu, that is almost $73 \%$, are migrants.

Guangzhou and Yiwu are 1,600 kilometers away from each other. Yiwu is 1/7 the size of Guangzhou, and its population is only $1 / 6$ that of Guangzhou. Both cities have developed rapidly since the reform and opening-up policy.

Guangzhou is famous as a trade center. Even now the Canton Fair that is held every spring and autumn is considered a very important trade event in China. In 2014, Guangzhou's GDP was 1.81 trillion RMB as both the manufacturing industry and light industry are developed in Guangzhou. Figure 1 below shows Guangzhou`s GDP growth.

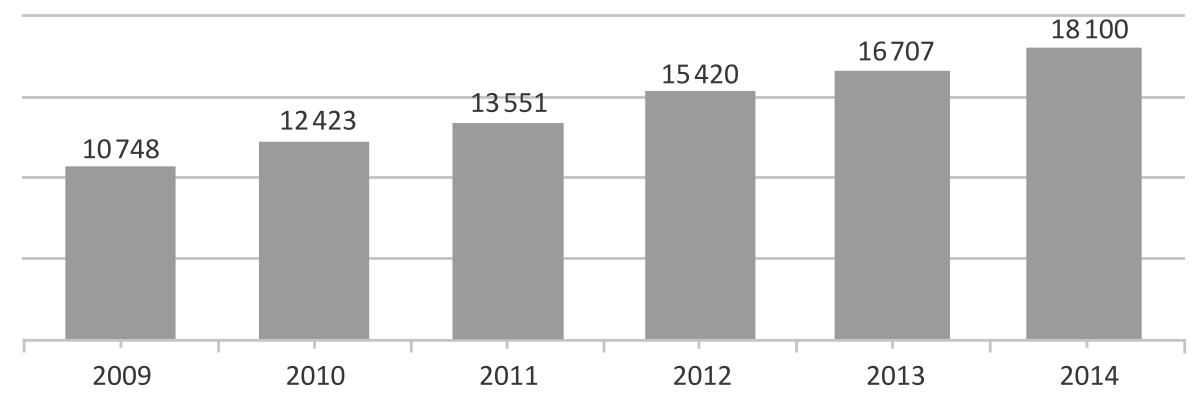

Fig. 1. Guangzhou's GDP 2009-2014

S o u r c e: The City of Guangzhou`s government website. Compiled by the author.

Being the world largest commodity market, Yiwu is also very well known as a trade center in China just like Guangzhou. In 2015, Yiwu`s GDP reached 104.6 billion RMB. Over 18 million types of merchandise attract traders from all over the world. The whole of Yiwu City represents a single market. Figure 2 illustrates Yiwu's GDP growth.

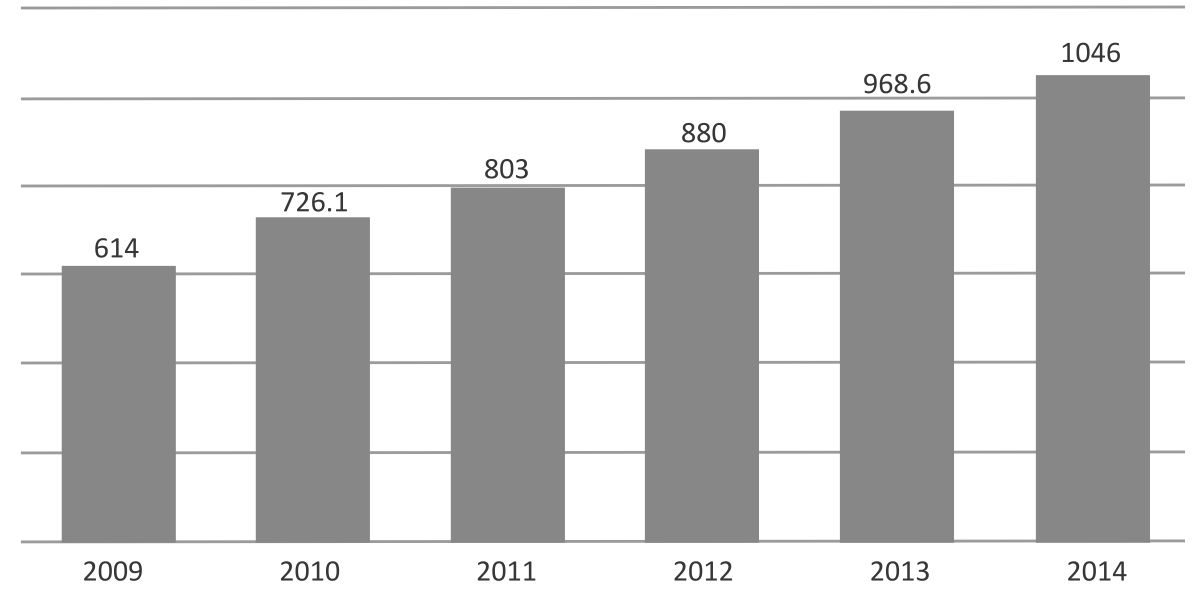

Fig. 2. Yiwu's GDP (2009-2014)

S o u r c e: The City of Yiwu's government website. Compiled by the author. 
In sum, being centers of trade, both Guangzhou and Yiwu attract foreign traders. Compared to Yiwu, Guangzhou is much larger in terms of city size, economy and population, which gives Guangzhou various advantages and, on the other hand, imposes more responsibilities that might also be considered a reason for attracting different kinds of migrants. Since the sizes of the cities are different, administration of foreigners is different in each city, especially on the local level. I will compare the administration of foreigners in the two cities in the next section.

\section{Local government administration of foreign residents}

A new law on administration of entry and exit of of foreigners was passed in the People's Republic of China in July 2013. Hereafter this law will be abbreviated as the law of 2013. It pays special attention to illegal immigration, overstaying and the employment of foreigners. In accordance with the law of 2013, the governments of Guangzhou and Yiwu issued their own regulations to supervise foreign residents.

At first, the Exit and Entry Control Department of the Guangzhou Municipal Public Security Bureau, based on local conditions, proclaimed the slogan "know numbers, control well, service well, and reduce crimes". Following this concept, Guangzhou established the first Community Office for the Assistance of Foreigners to supervise foreigners residing in Panyu district in $2008^{2}$. Offices were established in that area because many foreigners would often visit or stay there. In 2015, there were already 106 such offices around Guangzhou and its suburbs.

The major task of the offices is to register temporary addresses at the time that foreigners first move to Guangzhou, accept documents for visa photograph applications and manage all kinds of procedures. The offices must have an accurate grasp of the kinds of issues related to them, check the number of foreigners in the area, and carry out other kinds of work related to the residency of foreigners. Therefore, the main purpose of each such office is to monitor foreign residents and the areas where many of them reside, and, thus also venues where foreigners gather.

Photograph 1 shows a typical community office. The building on the left is an administration office of a local officer, who is in charge of registering foreign residents and receiving applications. The building on the right is a local police office that is in charge of employment of foreigners. This photo was taken in Yuexiu district, where the percentage of foreign residents is the highest in Guangzhou.

In 2013, according to the self-evaluation report of Yuexiu district ${ }^{3}$, one million foreigners visited the district. It was hardly possible to obtain the exact number of foreigners if they would not register voluntarily, so the local authorities in Yuexiu district independently established an office to register foreign residents. According to the above report, it has four methods of doing that.

The first measure can be called "one office, multiple working spots". Each community office handles all kinds of issues and establishes a number of working spots in residential areas where foreigners live which makes it possible to better understand their needs. The

2 News.163.com. URL: http://news.163.com/08/0119/22/42JQJN5F000120GU.html Retrieved on 23 May 2016.

3 The self-evaluation report of Yuexiu district about foreigners' management and services: http:// www.gdshjs.org/2xm/content/2013-07/10/content_73180015.htm. Retrieved on 2 April 2016. 


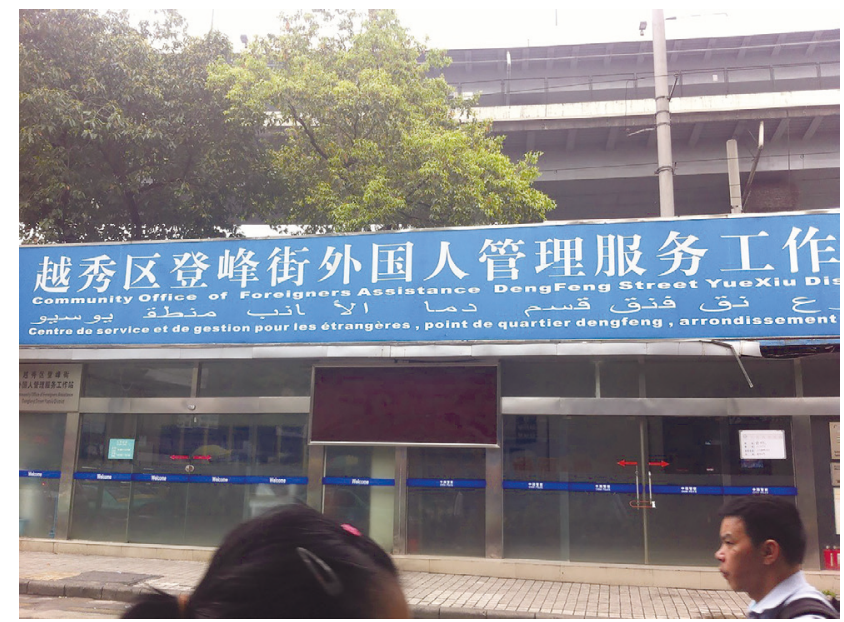

Photograph 1. Photograph by the author, September 2012

second measure is an online system in order to let foreigners do formalities directly online anytime. The system is convenient for registering and applying for a visa extension. The third one is to establish a so-called "model community". Every year the authorities select a community where foreigners live mixed with local residences without any incidents as a model. The community office recruits foreigners as volunteers, manages the community with the help of local residents, and promotes the mixed residence of foreigners and locals. The last measure is to attract the representatives of foreign chambers of commerce where foreigners are members, listen to their advice, and inquire after their needs in order to improve various services. In addition to the above-mentioned measures, the Yuexiu district office reorganized the department that administrated foreigners to better clarify the responsibilities of offices at the district level. They established a Foreigners' Affairs Service Center in lieu of a community office. This center deals with the whole range of issues related directly to foreigners. It is believed to be more efficient. Photograph 2 below shows the same place as photograph 1 . As we can see, the street became clean and beautiful. The sign above the entrance is smaller now and does not look as threatening as before.

On the other hand, Yiwu is the first county-level city that obtained the right to supervise immigration. The immigration office was established in 2005. It has been under the supervision of the Exit and Entry Control Department of Public Security of Zhejiang Province. Yiwu does not have community offices, but the Visa Management Service Center of the Yiwu Public Security Bureau is similar to the community offices in Guangzhou. At the service center, foreigners can register the address of their residence and apply for visas.

As the top officer of public security bureau of Yiwu, Zhi-qiang Li set the goal to "mix foreigners with local people" as his policy for foreigners ${ }^{4}$ [6, p. 36]. To achieve this purpose, he introduced the following six steps. The first was to establish temporary working spots for

${ }^{4}$ Gong an Ji guan Jing wai ren yuan guanli de xin tujing-Yiwu shi chuangjian "guoji shequ" de shijian yu sikao (The new approach to Foreigners administration for Public security Bureau-Practices and thinking of international community establishment by the city of Yiwu). Zhi-qiang Li, Journay of Zhejiang police college 2006(5): 36-38 


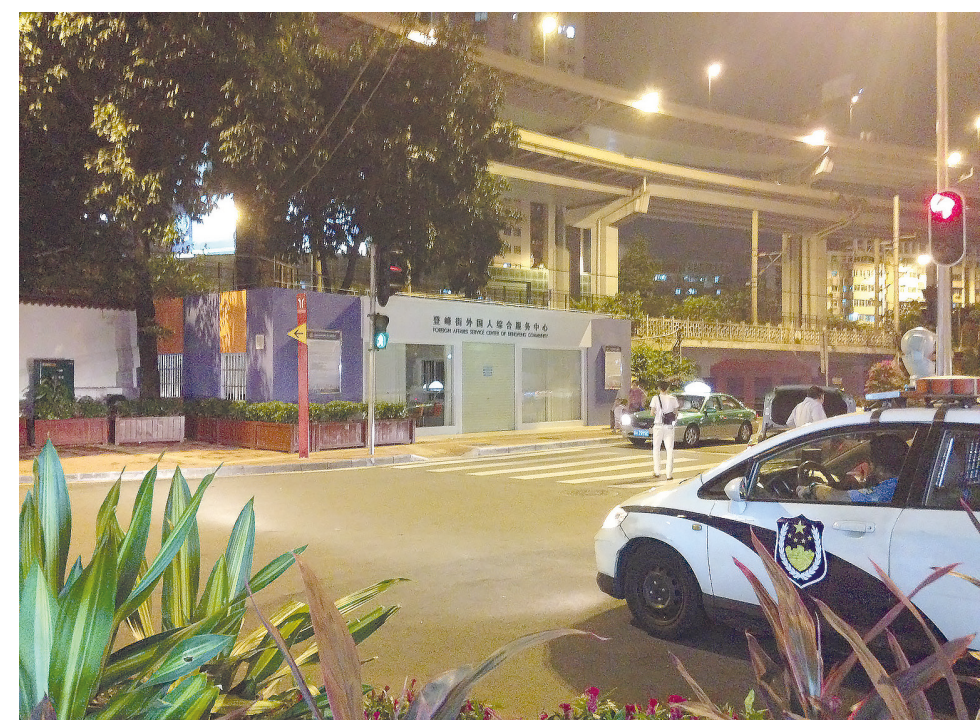

Photograph 2. Photograph by the author, 24 September 2015

foreigners to register in the community and to hire college students who can speak English as volunteers to help foreigners register. The second was to check the number of foreigners in the community by cooperating with those landlords who rent rooms to foreigners. The third step was to let foreigners who can speak Chinese fluently participate actively in community affairs. By doing that, he wanted to make foreigners feel at home when they lived in the community. He proposed starting free-of-charge Chinese language lessons; letting foreign children attend local schools; offered various suggestions to the local government on administration of foreigners; provided opportunities for religious events; and held happenings in communities, providing foreigners with a chance to communicate with local Chinese. The last step was the local administration office. Local police officers have to cooperate with each other, collecting information throughout the entire community in order to take preventive measures in terms of community affairs, etc [6, p. 36-38]

In contrast to Guangzhou's ethnic enclave, foreigners in Yiwu reside mixed with local Chinese, representatives of Chinese minority groups and domestic migrants.

The two cities have large floating populations that include not only foreigners but also domestic migrants. Because of the commercial activities in the two cities, they have attracted traders from developing countries. Guangzhou and Yiwu are both very attractive to Arab and African traders.

From the point of view of government policy, both cities first tried to survey the number of foreigners. The two cities also tried to make local communities assist in managing all issues related to foreign residents. Yiwu seems to be implementing policies successfully, but Guangzhou still has gaps.

As mentioned at the beginning of this study, foreigners in Guangzhou are more diverse in terms of the purpose of their residence compared to Yiwu. The diversity of their goals makes the administration of foreigners in Guangzhou more difficult than in the other city under consideration. Guangzhou still has a long way to go to achieve comparable results. 
Foreigners in Yiwu live mixed with local residents, while in Guangzhou the existence of an ethnic enclave allows foreigners to live without any need of communicating with the host society. Isolation has also opened a large gap between foreigners and the authorities. Foreigners do not trust authorities, while authorities consider the entire foreign group as a threat to public security.

\section{Migrants' networks}

Here, I would like to introduce some typical African migrants' networks in Guangzhou, based on the data garnered from my interviews in this city. These networks were formed according to the main activities of their members - religion, sports, and some others. All networks affected the life of African migrants in Guangzhou. Below is the basic information of the interviewees who are members of networks that I will introduce.

Table. Interviewees` information

\begin{tabular}{|c|c|c|c|l|}
\hline Interviewee & Country & Age & $\begin{array}{c}\text { The date of } \\
\text { the interview }\end{array}$ & \multicolumn{1}{|c|}{ The place of the interview } \\
\hline Pastor & Congo & 40 's & $26 / 9 / 2015$ & Church in the hotel \\
\hline J & Togo & 40 's & $26 / 9 / 2015$ & Church in the hotel \\
\hline C & Burundi & 20 & $24 / 9 / 2015$ & Guangdong University of Technology \\
\hline A & Congo & 25 & $24 / 9 / 2015$ & Guangdong University of Technology \\
\hline E & Guinea & 20 & $24 / 9 / 2015$ & Guangdong University of Technology \\
\hline Party host & Guinea & 40 's & $24 / 9 / 2015$ & At his home \\
\hline
\end{tabular}

Complied by the author.

Based on the data of these interviews, I briefly described some typical networks, which help African migrants to live safely in Guangzhou and pursue their religious activities.

\section{A religious network}

Guangzhou has a large church, which is called Shishi Sacred Heart Cathedral. It is located on the Yide Road. It organizes an English mass every Sunday afternoon from $2 \mathrm{pm}$ to $4 \mathrm{pm}$. A lot of African Christians visit the cathedral to pray every Sunday. They gather not only to pray, but also to meet friends, sing and enjoy some comfort.

In contrast to this church's large-scale activities, I also want to introduce a small church, which is located on Xiaobei Road, inside the ethnic enclave of African migrants, far away from the eyes of local people.

An interviewee introduced this church. He gave me a name card that he had received from a church representative as he was walking along Xiaobei Road. The person who gave him this name card and invited him to join the church was the pastor and the church founder. The card below is his name card.

The card is designed as an invitation to the church. It is written in English and French. The pastor's name and contact information are also written on the card. On the reverse side of the card, there is the church services program and schedule.

Since the address was written on the card, I wanted to visit the church by myself and checked the address online, then followed the map to search for it. It proved to be wrong, 

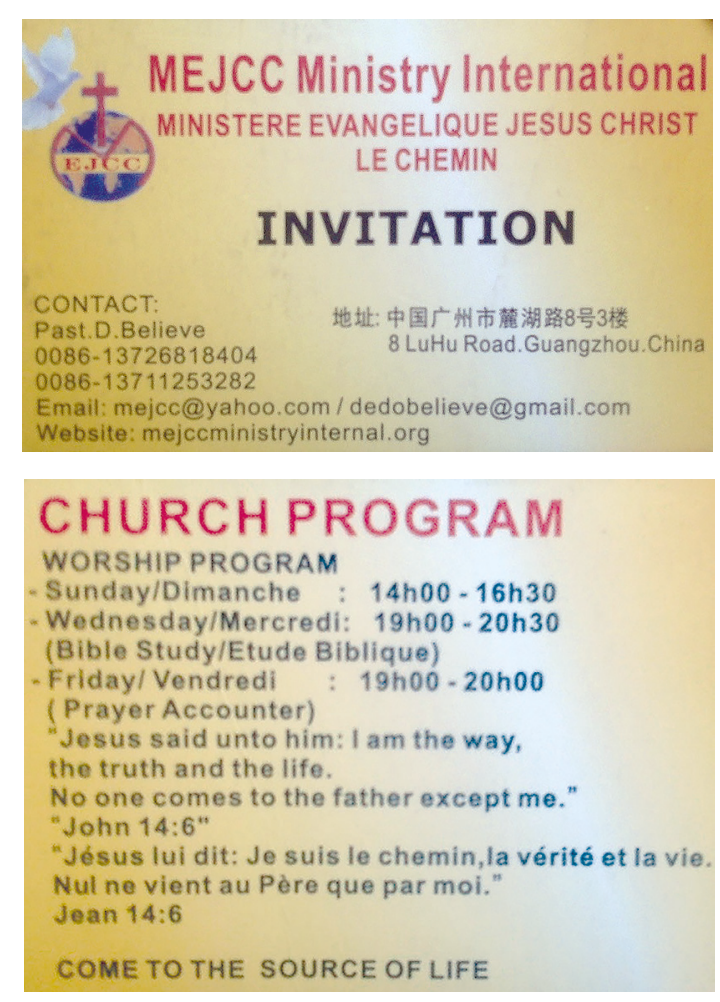

Photograph 3. Photograph by the author, 26 September 2016

because I could not find anything like a church at $8 \mathrm{Lu} \mathrm{Hu}$ Road. There were buildings number 7 and 6 , but no number 8 . According to the map, 8 was beside the hotel, but I could only find the hotel. I asked local residents, but no one seemed to know building number 8 .

It was fortunate that my interviewee who gave me the card could bring me to the church. The following Sunday he took me directly to the hotel that I had found before. We went onto the 3 rd floor, went through a long passageway without any lights inside the hotel and opened a small door at the end of the passage. This church was located there, on the hotel's 3rd floor. The two founders rented a hotel meeting room as a venue for the church gatherings. All the visitors were invited by the pastor or were brought by someone who had already been there before. Unless you happen to know a member of the congregation, it is nearly impossible to find the place.

The church was organized by two people. One is the pastor, and the other one is known as J. Both the pastor and J are businessmen in Guangzhou. They sell various kinds of merchandise. Both of them are married. The pastor's wife is from Africa, while J's wife is an internal migrant from another part of China. Both of them have been in Guangzhou for over 10 years. J has been there for 15 years. They started this church in January 2015, so when I interviewed them, the church had been operating for eight months. Currently, almost 30 people attend the mass every Sunday. The mass is held in English and French. Sometimes the pastor would use Chinese. The pastor's wife speaks Chinese very fluently. 
The church has six regular members besides the pastor and J. After a two-hour mass, regular members would come gather and study the Bible.

The pastor himself is originally from Congo, $J$ is originally from Togo, and the other regular members were born in different parts of Africa. However, in contrast to Africans at the Shishi Sacred Heart Cathedral, all the members of the small church are Francophone Christians.

I asked them why they wanted to open a church by themselves, and the pastor answered:

Sometimes it is plenty of (crowd of) people. So, sometimes it became this question. If the leader does not follow up all the members to know their life, to know what they're doing, to help in, to bring them back the right way, maybe people would not find their selves, what they are doing.

Initially, the pastor attended mass at the Shishi church, but he finally chose to do religious activities in his own way because, as he stated:

Maybe they are just using one language, if the brief is just in Chinese, or just in English, but we served many different countries, many languages, so we said that, Ok, maybe we can also start a team or a group to help people in different languages. In the church, we are Christians in English or in French; we have translation, even we pledge in Chinese. Even in English we translate it into Chinese. In that way we said OK, we can help people even us. All they want, they cannot fill in one church.

From this interview, we can see that African people from different countries stay in Guangzhou, thus they have various needs, not only in regard to their life in China, but also in regard to religious and other activities. The only church in Guangzhou seemed unable to satisfy every African Christian's spiritual needs. That is why this small secret church attracts people who keep coming.

Its two founders and six regular members are all successful businessmen in Guangzhou. They have resided in Guangzhou for a long time and can speak Chinese very well. That is why they need more spiritual support than short-term visitors do. Irregular members mostly are short-term visitors in Guangzhou, who live in the area around the ethnic enclave. They come and go, so the number of participants is unstable, but to most of them this church brings comfort. They feel to some degree dependent on it throughout their stay in China. This church community is fluid, its nucleus, however, is stable.

\section{A sports network}

$\mathrm{C}$ is an exchange student in Guangdong University of Technology and a football coach, being employed by a primary school in Jiangmen, which is a small town not far from Guangzhou.

A introduced C to me. A is also a student, but he has been in Guangzhou for five years. He learned Chinese during his first year, then he passed the entry examinations to Guangzhou University. His major is Chinese, which is very rare for an African student. Most of them will select IT or mechanical engineering. When I interviewed him in 2015, A was trying to continue his master's studies in Guangzhou. A is originally from Congo; he can speak English, French and Chinese fluently. He became my interpreter when I stayed in Guangzhou. 
A as a football player is affiliated with a local football club. He earns money from football games. He is paid one thousand RMB (almost 150 dollars) for each game. If the team wins, they receive a one-time payment (bonus). A is quite famous on the local football team because he led the team to victory many times. According to the rules of the legal Chinese football league, each team can hire up to three foreign players. African players became very popular with local football clubs because it is cheaper to hire them, and most of them play much better than local Chinese players.

A, C and other players from Africa know each other. They play football together by themselves and they exchange information about what local clubs are looking for players. The information is not limited to football clubs in Guangzhou, but also in Macau. Sometimes Hong Kong's professional teams also hire them if they really play well.

A has a friend, E, whose business visa expired and who stayed in Guangzhou, trying to find a football team that would employ him as a coach or a player. A introduced him to some clubs that sometimes needed players. These jobs covered his expenses in Guangzhou.

The football networks can be considered different from other networks. They are entirely informal, because members do not have an organization or place to gather, and they meet each other irregularly. They simply privately exchange information. A, for example, has information and wants to provide impartial assistance to his friends or compatriots. They even have a football game between the teams from all African countries. But the local football teams would leave foreign players uninformed once they get short of budget or for other reasons. The players do not have an insurance or any other kind of guarantee. That is why it was difficult for $\mathrm{E}$ to get an official football-related job in Guangzhou. However, as long as local Chinese football teams need players, the football network will function. It represents a type of entirely informal network, different from traders' networks.

\section{Friendship networks}

A invited me to his friend's house party. The party was helld by a successful businessman, who has been a resident of Guangzhou for five years. A told me that they gather to enjoy dinner every Friday. The host offered food and drinks. People come and go. The hostess kept asking the people if they wanted more food or not.

The host spends 3000RMB per month (almost 450 dollars) to rent the house. The area of the house is $40-50$ square meters; it is located in the middle of Xiaobei Road, near the ethnic enclave. The host's company is located in Foshan City in the suburbs of Guangzhou, but the businessman likes Xiaobei Road and rents this house here.

$\mathrm{He}$ and his wife are Muslims; he said that they pray in a friend's house but not in a mosque. That day, they had just finished their work and prayers. He and his wife invited all the friends he knew to join them, as most of his friends are single. He kept opening the door and greeting newcomers until midnight, and all friends were welcome. He has a large TV in the living room that shows French news through a satellite channel. Friends come to have food, watch TV and talk to each other.

E also came. He seemed comfortable and at ease even when unfamiliar people were around. It seemed that he did not need to worry about people informing local police about his illegal status. At 9:30 pm, when I said goodbye to them, they were still there.

This kind of mutual network can be seen only in the Francophone community. A successful businessman helps his friends because his life is better than theirs. The dinner party 
was just a small example of their activities. Some research shows that African businessmen will hire friends when they need employees, or supply them with useful information. All this assistance is private and devoid of financial interests.

\section{Conclusion}

All networks introduced in this article are located in Guangzhou, but there are some networks Yiwu also, founded on friendship and religious ties. Guangzhou has a greater variety of them. They were formed in various spheres of activities and in general help African migrants to get used to Guangzhou smoothly.

Guangzhou has a larger African population than Yiwu. That is the reason why networks in Yiwu are so different. The more people arrive, the more diversity and challenges they bring. To Guangzhou's authorities, the administration of foreign residents is more complicated than in Yiwu, while Yiwu seems to be friendlier to foreign residents.

Both cities are famous for trading, which might be considered an important factor that draws foreign merchants, in particular from developing countries, including Arab and African states. Both cities are similar in terms of having large floating populations, consisting not only of international but also internal migrants. Compared to Yiwu, Guangzhou is much larger in terms of economic activities and population. The administration of foreigners in Guangzhou includes various functions and a number of responsibilities.

As part of government policy, the two cities first tried to clarify the actual number of foreign residents. The administration of foreign residents is carried out according to official guidelines and with use of information gathered from foreigners. The two cities also tried to obtain cooperation of the local community to supervise foreign residents. It is likely to go smoothly in Yiwu, but Guangzhou still needs some improvements in this regard.

Foreigners come to Guangzhou with goals different to those who go to Yiwu. The diversity of their goals makes the administration of foreigners in Guangzhou more difficult than in Yiwu. On the other hand, foreigners in Yiwu live mixed with local residents, while in Guangzhou, the ethnic enclave allows Africans to live without integrating into the mainstream society. The isolation exposes a lack of mutual trust between foreigners and the authorities. Foreigners do not trust the authorities, while the authorities consider the entire foreign population a threat to public security. To Guangzhou's authorities, management of foreign residents is more complicated than in Yiwu, while Yiwu appears to be friendlier to foreign residents.

\section{References}

1. Bredeloup Sylvie. African Trading Post in Guangzhou: Emergent or Recurrent Commercial Form? African Diaspora, 2012, vol.5, pp. 27-50.

2. Li Zhi-qiang. Gong an Ji guan Jing wai ren yuan guanli de xin tujing-Yiwu shi chuangjian "guoji shequ" de shijian yu sikao [The new approach to the administration of foreigners for public security: Bureaucratic practices and thinking about the establishment of the international community in the city of Yiwu]. Journal of Zhejiang Police College, 2006 (5), pp. 36-38. (In Chinese)

3. Haugen Heidi Ostbo. Nigerians in China: A Second State of Immobility. International Migration, 2012, vol. 50, (2), pp. 66-79.

4. Kanamitsu Jun. Shakai netowaku bunnseki no kiso (Explanation of social network). Keiso shobo, 2004. (In Japanese) 
5. Lin Nan. Social Capital: A Theory of Social Structure and Action. Cambridge, Cambridge University Press, 2001.

6. Li Zhigang and Xue Desheng. Michael, et al. The African enclave of Guangzhou: A case study of Xiaobeilu. Acta Geographica Sinica, 2008, vol. 163, no. 2.

For citation: Ying Yang. African social networks in China: A comparative study of communities in Guangzhou and Yiwu. Vestnik SPbSU. Asian and African Studies, 2017, vol. 9, issue 4, pp. 416-428. https://doi.org/10.21638/11701/spbu13.2017.407

Received: 20.06.2017

Accepted: 31.08 .2017

Authors information

Yang Ying - Postgraduate; bifanchn@msn.com 